\title{
Advances in the diagnosis and treatment of liver fibrosis
}

\author{
Jenny Yeuk-Ki Cheng ${ }^{1,2}$, Grace Lai-Hung Wong ${ }^{1,2,3}$ \\ ${ }^{1}$ Institute of Digestive Disease, The Chinese University of Hong Kong, Shatin, Hong Kong 999077, China. \\ ${ }^{2}$ Department of Medicine and Therapeutics, 9/F Prince of Wales Hospital, Shatin, Hong Kong 999077, China. \\ ${ }^{3}$ State Key Laboratory of Digestive Disease, The Chinese University of Hong Kong, Shatin, Hong Kong 999077, China.
}

Correspondence to: Dr. Grace Lai-Hung Wong, Department of Medicine and Therapeutics, 9/F Prince of Wales Hospital, 30-32 Ngan Shing Street, Shatin, Hong Kong 999077, China. E-mail: wonglaihung@cuhk.edu.hk

How to cite this article: Cheng JYK, Wong GLH. Advances in the diagnosis and treatment of liver fibrosis. Hepatoma Res 2017;3:156-69.

\begin{tabular}{l} 
Article history: \\
Received: $25-06-2017$ \\
Accepted: $26-07-2017$ \\
Published: $08-08-2017$ \\
\hline Key words: \\
Chronic hepatitis B, \\
chronic hepatitis C, \\
fatty liver, \\
transient elastography \\
\end{tabular}

\begin{abstract}
Liver fibrosis is the center of diagnosis and management of essentially all chronic liver diseases. While liver biopsy examination still has a role in diagnosis and drug development, it is replaced by non-invasive assessments of liver biopsy in majority of the clinical scenarios. Radiological approaches, namely transient elastography, acoustic radiation force impulse imaging, shear wave elastography, magnetic resonance elastography provide accurate diagnosis of advanced fibrosis and cirrhosis. Serum test formulae based on common laboratory parameters or more specialized parameters including those commercially available panels FibroTest ${ }^{\mathbb{R}}$, FibroMeter $^{\mathbb{R}}$ and Enhanced Liver Fibrosis are also available. Combining different modalities may further improve the accuracy. The role of all these non-invasive assessments has been further expanded from diagnostic to prognostic, e.g. risk prediction of hepatocellular carcinoma (HCC) by LSMHCC score. Treatment of liver fibrosis can be achieved by controlling the underlying diseases, with chronic viral hepatitis as the most established disease model. Currently there are multiple clinical trials evaluating different treatment options to improve fibrosis in patients with nonalcoholic fatty liver disease. Specific anti-fibrotic treatment targets e.g. direct downregulation of hepatic stellate cell, collagen synthesis inhibitors and transforming growth factor- $\beta$ antagonists have been tested in laboratory and pending further studies in clinical settings.
\end{abstract}

\section{INTRODUCTION}

Liver fibrosis is the formation of scar tissue in response to parenchymal injury secondary to chronic liver disease, e.g. chronic hepatitis $B$ and $C$, non-alcoholic fatty liver disease (NAFLD) or alcoholism. It distorts the normal liver parenchyma. ${ }^{[1]}$ The continuous and progressive replacement of hepatocytes by extracellular matrix and fibrous tissue leads to liver cirrhosis, which is a key risk factor for hepatocellular carcinoma (HCC). ${ }^{[2]}$
Apart from its relationship with HCC, liver fibrosis is also an important treatment indication in various chronic liver diseases. Different international treatment guidelines mentioned that the severity of liver fibrosis should be considered, regardless of the level of ALT, for starting antiviral treatment for chronic hepatitis B (CHB). ${ }^{[3,4]}$ There are solid evidence supporting the fact that liver fibrosis is potentially reversible. ${ }^{[5]}$ Therefore, it is important to diagnose and assess the severity of liver fibrosis in order to provide appropriate

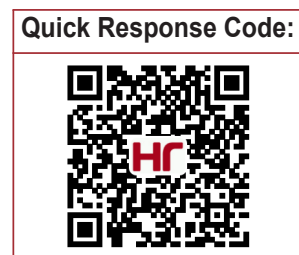


management in order to prevent further liver damage. This article focuses on the up-to-date approaches for diagnosis, both invasive and non-invasive, and latest development in treatments of liver fibrosis, particularly in NAFLD patients for whom a handful of clinical trials are currently ongoing.

\section{DIAGNOSIS OF LIVER FIBROSIS}

There are varieties of methods for making the diagnosis of liver fibrosis, which can be classified into invasive and non-invasive approaches.

\section{Invasive approach - liver biopsy examination}

For invasive approach, it refers to liver biopsy examination, which provides liver tissue for a histopathological assessment of liver. Liver biopsy examination can be done percutaneously, transvenously (either transjugularly or transfemorally), or surgically (open or laparoscopic operations). ${ }^{[6]}$ Indications for liver biopsy are for diagnostic and/or prognostic purposes, as well as for treatment planning. ${ }^{[7]}$

Liver biopsy is still regarded as the gold standard for liver fibrosis assessment in various chronic liver diseases. ${ }^{[8,9]}$ Apart from general histological staging, liver biopsy can also provide information concerning morphometry, which can provide additional information on the distribution and the exact quantity of liver fibrosis. ${ }^{[10]} A$ recent quantitative tool called qFibrosis utilized 87 parameters aiming for combining the results of collagen patterns, collagen architectural features and statistical analysis of features of respective collagen patterns into a single index. This requires an unstained biopsy sample for the automated analysis of liver fibrosis staging. ${ }^{[11]}$ All these evidences illustrate that liver biopsy plays an important role in the diagnosis of liver fibrosis.

Apart from liver fibrosis staging, liver biopsy can provide different information important for the management of the clinicians. For example, in cases of NAFLD, the degree of necroinflammation and steatosis can be determined by liver biopsy so corresponding management can be provided for this potentially reversible situation. ${ }^{[12]}$ Liver biopsy is also helpful in diagnosing adverse drug reaction and classification of liver tumors. ${ }^{[13]}$ Yet, the most common reason for conducting a liver biopsy is for assessing the liver fibrosis in patients with chronic viral hepatitis and NAFLD.

Such a direct and useful method bears quite a few limitations. Sampling error is a major limitation for liver biopsy as only $1 / 50,000$ of the whole liver parenchyma is obtained. Sampling error can be minimized by either obtaining a specimen of sufficient size (at least $2 \mathrm{~cm}$ in length) or from different lobes, which may not be feasible all the time. ${ }^{[14]}$ Well reported complications from liver biopsy examination include pain, ${ }^{[15]}$ bleeding such as wound bleeding, intraperitoneal hemorrhage, hemobilia or hemothorax, ${ }^{[15]}$ transient acute hypotension or vasovagal syncope. ${ }^{[16]}$ Fatal complications like uncontrolled bleeding, bacteremia and sepsis are rare but still possible. ${ }^{[17]}$ In patients with $\mathrm{HCC}$, liver biopsy also carries a risk of spreading the cancer cells. ${ }^{[18]}$

\section{Non-invasive approach}

Radiological assessments are either ultrasonographicbased [e.g. transient elastography, acoustic radiation force impulse (ARFI) imaging and shear wave elastography (SWE)] or magnetic resonance (MR)based [i.e. MR elastography (MRE)].

\section{Ultrasonographic based}

Transient elastography

Transient elastography (Fibroscan ${ }^{\circledR}$, Echosens, Paris, France) assesses liver stiffness measurement (LSM) by transmitting shear wave followed by ultrasound wave through a probe putting on the skin overlying the liver parenchyma. The velocity of the shear wave passing through the liver parenchyma is calculated by Doppler technique. The higher the velocity, the stiffer the liver parenchyma is. As mentioned by the manufacturer, for an examination to be considered as reliable, it requires at least 10 successful attempts and the ratio of interquartile range to median of those measurements should be less than 0.3. ${ }^{[19]}$ LSM reflects the degree of liver fibrosis. ${ }^{[20]}$ It can even identify those with no or minimal fibrosis and differentiate them from those with severe fibrosis or cirrhosis. ${ }^{[21]}$ It has been proved useful across different liver disease entity (e.g. chronic hepatitis B and C, autoimmune hepatitis). ${ }^{[22]}$ However, LSM by transient elastography is found to be less reliable in obese patients. ${ }^{[23,24]}$ It can be less accurate in certain situation, e.g. severe acute exacerbation of hepatitis, ${ }^{[25]}$ post-treatment fibrosis stages in $\mathrm{CHB}^{[26]}$ or chronic hepatitis $\mathrm{C}(\mathrm{CHC})$ patients. ${ }^{[27]}$

\section{ARFI imaging}

ARFI is another technique for estimating liver fibrosis. It is implemented in current ultrasound scanner, without acquirement of external equipment. The conventional ultrasound probe automatically produces an acoustic "push" pulse for generating shear-wave which passes through the tissue. The wave propagation speed is assessed. Again, higher the speed, higher the liver stiffness measurement is. ${ }^{[28,29]}$ There are several advantages for ARFI. As it is a function of the ultrasound 
scanner, no additional cost is required. ${ }^{[30]}$ The ARFI not only shows the degree of fibrosis, it also provides external information for disease progression for different chronic liver disease, for example HCV. ${ }^{[31]}$ Another advantage of this tool is that it can provide real-time results and easy to perform. The measurement results appear to be more accurate in overweight and obese patients, compared with transient elastography. ${ }^{[32]}$ However, one prominent disadvantage for ARFI is that the range of its measurement is quite narrow (only from 0.5 to $4.4 \mathrm{~m} / \mathrm{s}) \cdot{ }^{[33]}$ Furthermore, it is quite difficult to match the degree of fibrosis with the wave propagation speed, i.e. a cut-off, which is difficult to be defined. ${ }^{[34]}$

\section{SWE}

SWE is a 2-dimensional ultrasound technique based on the estimation of shear wave velocity from the radiation force of a focused beam of ultrasound, ${ }^{[35]}$ and it can be converted results in terms of $\mathrm{kPa}$ by an equation. ${ }^{[36]}$ No extra vibrator or detector is required as it is integrated into a conventional ultrasound system. Besides, elasticity of liver tissues can be shown in both numerical values and color (i.e. higher stiffness is reflected in red color), which can reflect the relative stiffness of the liver tissue quickly. The numerical values can be expressed in either $\mathrm{kPa}$ or $\mathrm{m} / \mathrm{s}$, which can be comparable with the results from transient elastography or ARFI. ${ }^{[37]}$ Actually, its accuracy is higher compared to transient elastography or AFRI in assessing the degree of fibrosis, especially in those with early-stage liver fibrosis. ${ }^{[38]}$ SWE with spleen stiffness index is recommended as the first line assessment for patients with liver fibrosis due to chronic hepatitis $C$ in the latest guidelines. ${ }^{\left[{ }^{[3]}\right.}$ However, only a few studies validate its clinical application. ${ }^{[38,40]}$

\section{MRE}

MRE adopts a phase contrast imaging method which depends on mechanical wave propagation to assess the degree of liver stiffness. ${ }^{[41]}$ Generally, MRE is less operator-dependent and involved in less technical failure. The global picture of the liver can be viewed easily, regardless the obesity or severity of the ascites of the patients. It can also give a comprehensive assessment for the associated complications, for example portal hypertension or associated spleen stiffness. ${ }^{[42]}$ Meanwhile, it is useful for diagnosis and staging of liver fibrosis, even if the fibrosis is very mild. Another advantage for MRE is that the results are readily reproducible. ${ }^{[42]}$ However, MRE is more expensive and time-consuming compared to ultrasound-based approach. Respiration creates artifacts on the images. Another important limitation is that it is not applicable on patients with iron overload, or hemochromatosis, because iron might create noise for the signals received by the MR machine. ${ }^{[43]}$ There are still limited studies mentioning the clinical significance of MRE results. Even though it is apparently sensitive to mild liver fibrosis, the result may sometimes be unreliable. ${ }^{[44]}$

\section{Serum test formulae}

\section{Common laboratory parameters}

Another commonly adopted non-invasive assessment is based on serum with or without clinical parameters. Examples including common parameters in clinical practice include aspartate aminotransferase (AST) to platelet ratio index (APRI), ${ }^{[4]}$ Forns index, ${ }^{[46]}$ Fibrosis-4 (FIB-4), ${ }^{[4]}$ Fibroindex,${ }^{[48]}$ Hui index,${ }^{[49]}$ NAFLD fibrosis score (NFS) $)^{[50]}$ and BAAT score ${ }^{[51]}$ [Table 1]. These parameters are derived from routine liver biochemistry panel, so it is quite convenient. These parameters are also technically easy to obtain and with minimal interobserver variations. Patients with advanced fibrosis can be identified by these tests. ${ }^{[52]}$ However, these parameters are often validated in just one or two liver diseases. For example, two scoring systems for $\mathrm{CHC}$ patients, namely APRI and FIB-4, are found to be not useful in CHB patients. ${ }^{\left[{ }^{[3]}\right.}$

\section{FibroTest ${ }^{\circledR}$}

Some specific biochemical parameters related to fibrinolysis or fibrinogenesis are developed to improve the specificity of liver fibrosis assessment [Table 2]. One example is FibroTest ${ }^{\circledR}$ (BioPredictive, Paris, France; or known as Fibrosure ${ }^{\circledR}$ in the United States ) consists of 5 components, namely GGT, total bilirubin, $\alpha-2$ macroglobulin, apolipoprotein $A 1$, and haptoglobin. Sometimes, another test, ActiTest, would also perform together with FibroTest ${ }^{\circledR}$ for assessment for liver activity, with the additional measurement of ALT. The results would be adjusted according to age and gender. ${ }^{\left[{ }^{[4]}\right.}$ FibroTest $^{\circledR}$ is originally used in patients with $\mathrm{CHC} .{ }^{[55]}$ Nowadays it is recommended by different associations concerning liver studies for evaluation of liver fibrosis in patients with CHB, NAFLD or alcoholic liver disease. ${ }^{[56-58]}$ It is highly reliable and applicable, ${ }^{[59]}$ even for patients with obesity. ${ }^{[60]}$ It performs well for diagnosis of liver cirrhosis for disease entities other than $\mathrm{CHC}$. However, the results are suboptimal for detecting earlier stages before cirrhosis. ${ }^{[61]}$

\section{FibroMeter $^{\circledR}$}

FibroMeter $^{\circledR}$ (Echosens, Paris, France) has been validated in patients with $\mathrm{CHB}, \mathrm{CHC}$, NAFLD and alcoholic liver disease. ${ }^{[62]}$ Platelets, prothrombin index, AST, $\alpha-2$ macroglobulin, hyaluronate, urea and age are taken into accounts. ${ }^{[63]}$ Second generation (2G) has put age into another important parameter. ${ }^{[62]}$ FibroMeter ${ }^{\circledR}$ has recently reached its third generation 
Table 1: Serum test formulae for liver fibrosis

\begin{tabular}{ll}
\hline Parameters or index & Formula \\
\hline APRI & AST $(\mathrm{ULN}) \times 100 /$ platelet $\left(10^{9} / \mathrm{L}\right)$ \\
Forns index & $7.811-3.131 \times \ln ($ platelet count $)+0.781 \times \ln (\mathrm{GGT})+3.467 \times \ln ($ age $)-0.014 \times($ cholesterol $)$ \\
FIB-4 & Age $($ years $) \times \mathrm{AST}[\mathrm{U} / \mathrm{l}] /\left(\right.$ platelets $\left.\left[10^{9} / \mathrm{L}\right] \times(\mathrm{ALT}[\mathrm{U} / \mathrm{L}])^{1 / 2}\right)$ \\
Fibro index & $1.738-0.064 \times$ platelet $\left.\left[10^{9} / \mathrm{L}\right]\right)+0.005 \times \mathrm{AST}[\mathrm{IU} / \mathrm{L}]+0.463 \times$ gamma globulin $[\mathrm{g} / \mathrm{dL}]$ \\
Hui index & $\exp \left(3.148+0.167 \times \mathrm{BMI}+0.088 \times\right.$ bilirubin $[\mu \mathrm{mol} / \mathrm{L}]-0.151 \times$ albumin $\left.[\mathrm{g} / \mathrm{L}]-0.019 \times \mathrm{platelet}\left[10^{9} / \mathrm{L}\right]\right) /(1+$ \\
& $\exp \left(3.148+0.167 \times \mathrm{BMI}+0.088 \times\right.$ bilirubin $[\mu \mathrm{mol} / \mathrm{L}]-0.151 \times$ albumin $[\mathrm{g} / \mathrm{L}]-0.019 \times$ platelet $\left.\left.\left[10^{9} / \mathrm{L}\right]\right)\right)$ \\
NFS & $-1.675+0.037 \times$ age $($ years $)+0.094 \times \mathrm{BMI}\left(\mathrm{kg} / \mathrm{m}^{2}\right)+1.13 \times$ impaired fasting glycaemia or diabetes $($ yes $=1$, no \\
& $=0)+0.99 \times \mathrm{AST} / \mathrm{ALT}$ ratio $-0.013 \times$ platelet $\left(\times 10^{9} / \mathrm{L}\right)-0.66 \times$ albumin $(\mathrm{g} / \mathrm{dL})$ \\
BAAT score & BMI $(\geq 28=1,<28=0)+$ age at liver biopsy $(\geq 50$ years $=1,<50=0)+\mathrm{ALT}(\geq 2 \times(\mathrm{ULN})=1,<2 \times \mathrm{ULN}=0)$ \\
& + serum triglycerides $(\geq 1.7$ mmol/L $=1,<1.7=0)$ \\
\hline
\end{tabular}

ALT: alanine aminotransferase; APRI: aspartate aminotransferase to platelet ratio index; AST: aspartate aminotransferase; BAAT: BMI, age, ALT, triglycerides; BMI: body mass index; FIB-4: fibrosis-4; GGT: gamma-glutamyl transferase; NFS: non-alcoholic fatty liver disease (NAFLD) fibrosis score; ULN: upper limit of normal

Table 2: Different non-invasive approach

\begin{tabular}{|c|c|c|c|}
\hline Non-invasive tests & Features & Advantages & Disadvantages \\
\hline \multicolumn{4}{|l|}{ Radiological } \\
\hline $\begin{array}{l}\text { Transient } \\
\text { elastography }\end{array}$ & $\begin{array}{l}\text { Ultrasound-based liver stiffness } \\
\text { measurement by shear wave } \\
\text { velocity by a specific probe }\end{array}$ & $\begin{array}{l}\text { Useful across different liver disease entity } \\
\text { Special probes designed for different body } \\
\text { built } \\
\text { Measure liver fat at the same time with } \\
\text { CAP } \\
\text { Can identify no or minimal fibrosis }\end{array}$ & $\begin{array}{l}\text { Less reliable in obese patients } \\
\text { Less reliable in severe acute } \\
\text { exacerbation of hepatitis } \\
\text { Less reliable in post-treatment } \\
\text { fibrosis stages in CHB or CHC } \\
\text { patients }\end{array}$ \\
\hline $\begin{array}{l}\text { Acoustic radiation } \\
\text { force impulse } \\
\text { imaging }\end{array}$ & $\begin{array}{l}\text { Ultrasound-based wave } \\
\text { propagation speed measurement } \\
\text { by conventional probe }\end{array}$ & $\begin{array}{l}\text { No additional apparatus except ultrasound } \\
\text { machine } \\
\text { Can reflect disease progression } \\
\text { Real-time results } \\
\text { Less technical difficulties } \\
\text { Accurate in overweight or obese patients }\end{array}$ & $\begin{array}{l}\text { Narrow range of measurement } \\
\text { Difficult to define a cut-off } \\
\text { More experienced operators need }\end{array}$ \\
\hline $\begin{array}{l}\text { Shear wave } \\
\text { elastography }\end{array}$ & $\begin{array}{l}\text { Ultrasound measurement of shear } \\
\text { wave velocity }\end{array}$ & $\begin{array}{l}\text { No additional apparatus except ultrasound } \\
\text { machine } \\
\text { Elasticity can be reflected by numbers or } \\
\text { colors } \\
\text { Sensitive for early-stage fibrosis } \\
\text { Results can be expressed into } \mathrm{kPa} \text { or } \mathrm{m} / \mathrm{s}\end{array}$ & $\begin{array}{l}\text { Limited studies on its clinical } \\
\text { application }\end{array}$ \\
\hline $\begin{array}{l}\text { Magnetic resonance } \\
\text { elastography }\end{array}$ & $\begin{array}{l}\text { Phase contrast imaging depending } \\
\text { on mechanical wave propagation }\end{array}$ & $\begin{array}{l}\text { Less operator-dependent and less } \\
\text { technical failure } \\
\text { Limited effect by obesity or ascites } \\
\text { Can assess complications } \\
\text { Sensitive for early-stage fibrosis } \\
\text { Reproducible results }\end{array}$ & $\begin{array}{l}\text { High cost } \\
\text { Limited availability in some countries/ } \\
\text { regions } \\
\text { More time-consuming } \\
\text { Not applicable on patients with iron } \\
\text { overload or hemochromatosis } \\
\text { Limited studies on its clinical } \\
\text { application }\end{array}$ \\
\hline \multicolumn{4}{|l|}{ Serum test formulae } \\
\hline $\begin{array}{l}\text { Common laboratory } \\
\text { parameters }\end{array}$ & Refer to Table 1 & $\begin{array}{l}\text { Results from routine liver function test, } \\
\text { convenient to perform } \\
\text { No inter-observer variations }\end{array}$ & $\begin{array}{l}\text { Cannot be used for all chronic liver } \\
\text { diseases }\end{array}$ \\
\hline FibroTest & $\begin{array}{l}\text { Consists of GGT, total bilirubin, } \alpha-2 \\
\text { macroglobulin, apolipoprotein A1, } \\
\text { and haptoglobin }\end{array}$ & $\begin{array}{l}\text { Useful in different chronic liver disease } \\
\text { Reliable } \\
\text { Applicable } \\
\text { Accurate in overweight or obese patients }\end{array}$ & Suboptimal for early stage fibrosis \\
\hline FibroMeter & $\begin{array}{l}\text { First } 2 \text { generations: consists of } \\
\text { platelets, prothrombin index, AST, } \\
\alpha-2 \text { macroglobulin, hyaluronate, } \\
\text { urea and age } \\
\text { 3rd generation (3G): hyaluronate } \\
\text { does not take into account }\end{array}$ & $\begin{array}{l}\text { With high fibrosis classification accuracy } \\
\text { Good predictive value for severe fibrosis in } \\
\text { different liver disease entities }\end{array}$ & High cost \\
\hline $\begin{array}{l}\text { Enhanced liver } \\
\text { fibrosis }\end{array}$ & $\begin{array}{l}\text { Consists of } 3 \text { direct blood markers: } \\
\text { procollagen III amino terminal } \\
\text { peptide, hyaluronic acid and tissue } \\
\text { inhibitor of metalloproteinase I }\end{array}$ & $\begin{array}{l}\text { Good prognostic factor for clinical } \\
\text { outcomes in patients with chronic liver } \\
\text { diseases } \\
\text { Similar results by using fresh blood or } \\
\text { cryopreserved blood } \\
\text { Sensitive for advanced fibrosis or cirrhosis }\end{array}$ & $\begin{array}{l}\text { Not sensitive for early stages of } \\
\text { fibrosis } \\
\text { Age, low CD4+ T-cell count and } \\
\text { other factors can affect ELF results }\end{array}$ \\
\hline
\end{tabular}

AST: aspartate aminotransferase; CAP: controlled attenuation parameter; CHB: chronic hepatitis B; CHC: chronic hepatitis C; ELF: enhanced liver fibrosis 
(3G), which does not take hyaluronate into account. Therefore, the cost has been reduced but with similar effectiveness. ${ }^{[64]}$ FibroMeter $^{\circledR}$, both $2 G$ and $3 G$, has been shown with high fibrosis classification accuracy. ${ }^{[65]}$ Besides, it appears to have a good predictive value towards the occurrence of severe fibrosis in those with NAFLD ${ }^{[66]}$ and chronic hepatitis B or C. ${ }^{[67]}$ Even though the hyaluronate-free FibroMeter ${ }^{\circledR} 3 G$ is in use nowadays, the cost is still high compared to common parameters (e.g. FIB-4 or NFS). ${ }^{[68]}$

\section{Enhanced liver fibrosis}

Enhanced liver fibrosis (ELF) score is an algorithm consists of 3 direct markers in blood, namely procollagen III amino terminal peptide (PIIINP), hyaluronic acid and tissue inhibitor of metalloproteinase I (TIMP-I). ${ }^{[6]}$ ELF can be a good prognostic factor for the clinical outcomes of patients with chronic liver disease. The increase in one point in ELF can lead to doubling of the risk of clinical outcomes in patients, especially liver-related clinical outcomes. ${ }^{[70]}$ ELF results are even similar when using fresh blood or cryopreserved blood. Therefore, it has a high predictive value for identifying patients with risk to develop progressive chronic liver disease at an early stage ${ }^{\left[{ }^{71]}\right.}$ It is sensitive in identifying advanced fibrosis or cirrhosis, but not for lower fibrosis stage. ${ }^{[72,73]}$ Meanwhile, it is noted that different factors can influence the result of ELF score, with the most significant factor being age. ${ }^{[74]}$ Other factors include low CD4+ T-cell count, co-existing extra-hepatic fibrosis, etc. ${ }^{[75]}$ Therefore, the results of ELF should be interpreted with particular clinical context.

\section{Novel serum markers}

There are some other novel serum fibrosis markers that raise the attention of the clinicians. Glycosylated Wisteria floribunda agglutinin-positive Mac-2 binding protein (WFA $\left.{ }^{+}-\mathrm{M} 2 \mathrm{BP}\right)$ is a marker which is related to fibrosis-related glyco-alteration. It can be measured by a glycan-based immunoassay, FastLec-Hepa. A cutoff index would be calculated based on the measured value. ${ }^{[76]}$ It is found to be useful for detecting early stages of fibrosis in chronic hepatitis $B$ patients in a recent study. ${ }^{[77]}$ Another novel marker, YKL-40 (CHI3L1), is an emerging inflammation biomarker which was shown to be related to the early stage of liver fibrosis. ${ }^{[78]}$ In NAFLD patients, macrophages in liver were showed to express YKL-40. This makes YKL-40 be possible as a biomarker as liver fibrosis. ${ }^{[79]}$ However, further studies need to be conducted to show the effectiveness and impact of both biomarkers on making the diagnosis or management of patients with liver fibrosis due to any chronic liver diseases.

\section{Combination of different approaches}

It is common for using both radiological and biochemical methods to increase the accuracy in determining the degree of fibrosis. Both types of methods can play a supplementary role to each other. For example, the performance of ELF improves with the assistance of transient elastography. ${ }^{[80]}$ With the use of ELF-LSM algorithm, a significant proportion of patients can avoid liver biopsy. ${ }^{[69]}$ Another example is Hui Index and transient elastography. Since LSM result is confounded in patients with elevated ALT, Hui index, a score independent of ALT level, is a good choice for supplementation of transient elastography. Studies have shown that the combinations can help predict hepatic event-free survival in chronic hepatitis $B$ patients. ${ }^{[81]}$ Another combination for assessment of liver fibrosis in CHB patients is Forns index (another ALT-free index)-LSM algorithm. ${ }^{[82]}$ FibroMeter $^{\circledR}$ and transient elastography combined together can help improve diagnostic accuracy and avoid liver biopsy in $\mathrm{CHC}$ patients. ${ }^{[83]}$ For the diagnosis of cirrhosis in $\mathrm{CHC}$ patients, using the algorithm FibroTest ${ }^{\circledR}$ and transient elastography improves the performance. However, this combination does not show extra benefit for diagnosis of advanced fibrosis compared to the sole use of FibroTest $^{\circledR} .{ }^{84]}$

\section{Non-invasive tests - from diagnostic to prognostic}

\section{Portal hypertension and related complications}

The role of all these non-invasive tests is moving from diagnostic to prognostic. They are useful to predict liver-related complications and hence the prognosis of patients with chronic liver diseases. For example, a LSM with $13.6 \mathrm{kPa}$ can be a predictive value the presence of portal hypertension. ${ }^{[85]}$ Combing LSM with APRI or Fibroindex increases the sensitivities for portal hypertension predication. ${ }^{[85]}$ Liver stiffness with ARFI greater than $2.34 \mathrm{~m} / \mathrm{s}$ indicates a poor liver reserve function. ${ }^{\left[{ }^{[6]}\right.}$ Assessment of spleen loss modulus by MRE is a good method for recognizing patients with severe portal hypertension or esophageal varices with high bleeding tendency. ${ }^{[87]}$ Combing LSM and spleen stiffness measurement (SSM) may exclude the presence of large esophageal varices with high sensitivity ${ }^{[88]}$ and can be adopted in the risk stratification and variceal screening strategy. ${ }^{[89]}$

\section{Survival}

Survival for chronic liver disease can be predicted using non-invasive test. LSM $^{[90,91]}$ or FibroTest ${ }^{\circledR}$ has a high prognostic value for patients with chronic viral hepatitis. ${ }^{[92,93]}$ The usage of LSM and Hui index for predicting hepatic-event free survival in CHB patients is shown to be accurate. ${ }^{[81]}$ FibroMeter $^{\circledR}$ is shown to be useful for assessment of liver prognosis in $\mathrm{CHC}$ patients with milder disease.${ }^{[94]}$ ELF score can be used 
to assess transplant-free survival of the patients with primary sclerosing cholangitis, ${ }^{[95]} \mathrm{HCV} / \mathrm{HIV}$ co-infected women ${ }^{[96]}$ and the prognosis if patients with different chronic liver diseases. ${ }^{[70]}$

\section{HCC}

There is good evidence show the strong predictive and even diagnostic role of the non-invasive tests for HCC. ARFI is used for differentiating benign and malignant liver tumors by the assessment of virtual touch tissue imaging (VTI) and virtual touch tissue quantification (VTQ), as VTI appears to be stiffer and VTQ is higher in malignant lesion than its benign counterpart. ${ }^{[97]}$ For MRE, the measurement of loss modulus in liver tumor can help differentiating the benign lesions from the malignant ones, with the former having a lower value. ${ }^{\text {[98] }}$ Non-invasive test is also an important part of some HCC risk score. For example, LSM-HCC score, which is optimized from CU-HCC score with LSM, further increases the negative predictive value to close to $100 \%$ for HCC prediction in 3 to 5 years in CHB patients. ${ }^{\text {[9] }}$ Both FibroTest and LSM results can help predict the occurrence of HCC in patients with viral hepatitis. ${ }^{[100]}$ Patients with ELF higher than 10.4 is known to have higher risk of liver-related events, in which HCC is at the top of the list. ${ }^{[101]}$ Non-invasive tests can also play some part in prognosis of HCC. For example, in HCC patients receiving partial hepatectomy or transarterial chemoembolization, LSM and APRI is an independent prognostic factor. ${ }^{[90,91,102]}$

\section{TREATMENT OF LIVER FIBROSIS}

\section{Treatment for underlying diseases}

With very potent antiviral agents, patients with chronic viral hepatitis often have liver fibrosis and even cirrhosis regressed after sustained viral suppression or viral clearance. ${ }^{[103,104]}$

\section{$\mathrm{CHB}$}

There is ample evidence to support the fact that effective antiviral treatment reverses liver fibrosis in majority of CHB patients. ${ }^{[104,105]}$ Cumulative entecavir therapy for 3 to 7 years regressed liver fibrosis in $88 \%$ of $57 \mathrm{CHB}$ patients, including all 10 patients with advanced fibrosis or cirrhosis. ${ }^{[105]}$ This observation was further confirmed by a larger cohort of 348 patients who tenofovir disoproxil fumarate, in which $176(51 \%)$ had regression of fibrosis at week 240. ${ }^{[104]}$ More importantly, most (71\%) patients with cirrhosis at baseline had regression of cirrhosis. Data from the same trial revealed that body mass index at baseline was the single negative predictor of liver fibrosis regression. ${ }^{[106]}$

Importance of metabolic factors on liver fibrosis regression was also supported by data from Chinese and Korean cohorts established that metabolic syndrome is a risk factor of advanced liver fibrosis and cirrhosis independent of viral factors in $\mathrm{CHB} .{ }^{[107,108]}$ New-onset metabolic syndrome and some of its components (namely central obesity and low highdensity lipoprotein cholesterol) were found associated with liver fibrosis progression, independent of change in viral load and ALT level. ${ }^{[109]}$ Therefore controlling metabolic factors in CHB patients already have good viral suppression with antiviral treatment would be important, not only to enhance liver fibrosis regression and hepatic events, but also to minimize cardiovascular death. ${ }^{[110]}$

Indirect evidence of antiviral treatment reversing liver fibrosis also came from two studies using serial LSM results to assess the change in liver fibrosis in large cohorts of asymptomatic CHB patients revealed low incidence rate of liver fibrosis progression, defined as an increase in LSM by $30 \%$ or more. ${ }^{[111,112]}$ It was because patients who had active disease, as evidenced by raised ALT and high HBV DNA, had been started on antiviral treatment.

\section{$\mathrm{CHC}$}

Data from last century illustrated the conventional interferon regresses liver fibrosis in $\mathrm{CHC}$ patients with sustained virologic response (SVR). ${ }^{[13]}$ Similar findings have been reported in sustained responders to pegylated interferon. ${ }^{[114,115]}$ Regression of liver fibrosis, which occurred in $82 \%$ of patients, was sustained at 5 years after SVR; more impressively recovery of normal or nearly normal liver architecture is possible. ${ }^{[103]}$

Now it is the era of direct-acting antiviral (DAA) agents in treating $\mathrm{CHC}$ patients, which leads to an SVR close to $100 \% .{ }^{[116]}$ Studies evaluating liver fibrosis regression in DAA-treated $\mathrm{CHC}$ patients often adopted non-invasive assessments like transient elastography. A small study of 54 DAA-treated patients with baseline cirrhosis revealed more pronounced reduction in LSM happened between baseline to end-of-treatment visit, but less obvious in the post-treatment period. Hence the authors concluded that decreased LSM was likely accounted by the reduced necroinflammation and probably to a less extent to regression of cirrhosis. ${ }^{[117]}$ Another study of larger sample size already made use of serum makers on top of LSM revealed that FIB-4 and APRI improved to the same extent of LSM after SVR. ${ }^{[118]}$ Yet whether this indicated a true regression of fibrosis or merely resolution of chronic liver inflammation remained to be determined. ${ }^{[118]}$

NAFLD

Similar to chronic viral hepatitis, controlling underlying 
metabolic risk factors is central in the management to improved liver fibrosis in NAFLD patients. A weight reduction of $10 \%$ or more by aggressive lifestyle modification appears to resolve fibrosis in most if not all cases (at least with mild-moderate fibrosis). ${ }^{[119,120]}$ Thiazolidinediones [peroxisome proliferator-activated receptor (PPAR)- $\gamma$ agonists] such as pioglitazone and rosiglitazone are insulin sensitizers and were found to be effective to reduce fibrosis in two metaanalyses; ${ }^{[121,122]}$ but the finding was not confirmed when more recent and bigger studies were included in the analysis. ${ }^{[123]}$ The largest study of pentoxiphylline and also a recent study of obeticholic acid both showed a significant reduction of fibrosis ${ }^{[124]}$ the magnitude was not pathologically significant (far less than one fibrosis stage by the non-alcoholic steatohepatitis (NASH) Clinical Research Network system. ${ }^{[125]}$

In terms of pharmacological agents, there has been much interest in anti-fibrotic therapy in NAFLD as fibrosis is one of the strongest prognostic markers for NAFLD. Lysyl-oxidase like 2 (LOXL2) is involved in a relatively late step in hepatic fibrogenesis, the crosslinking of extracellular matrix proteins such as collagen and elastin. ${ }^{[126]}$ Simtuzumab, a humanized monoclonal anti-LOXL2 antibody was once evaluated in Phase 2 trials in nonalcoholic steatohepatitis (NASH) patients with significant fibrosis and cirrhosis. ${ }^{[127]}$ Nonetheless, the pharmaceutical company developed this agent announced it discontinued testing of simtuzumab, as it failed to show efficacy in Phase 2 trials of $\mathrm{NASH}$ as well as primary sclerosing cholangitis. ${ }^{[128]}$ More recent data also support that the hepatic expression of the apoptosis signal-regulating kinase 1 (ASK1) marker, phosphorylated-P38 (p-P38), correlates with fibrosis stage in patients with NAFLD. ${ }^{[129]}$ Therefore, selonsertib, an oral molecule that inhibits ASK1, together with simtuzumab, was found to be effective to regress liver fibrosis in NASH patients with stage 2 or 3 fibrosis. Selonsertib alone is currently evaluated in NASH patients with advanced fibrosis and cirrhosis (Clinicaltrials.gov Identifier NCT03053050 and NCT03053063) [Table 3].

Cenicriviroc is a C-C chemokine receptor type 2 and type 5 (CCR2/CCR5) antagonist, which interrupts the inflammatory cascade in NASH that leads to fibrogenesis. In animal models, the drug has been shown to have anti-inflammatory and anti-fibrotic activity. ${ }^{[130,131]}$ In an ongoing two-year Phase $2 b$ trial with cenicriviroc, it significantly improved liver fibrosis for at least one stage at 48 weeks when compared to placebo (20\% vs. $10 \% ; P=0.023) .{ }^{[132]}$ Galectins are cell surface glycoproteins that can mediate cell migration, matrix interaction and inflammatory signals. GRMD-02 and GM-CT-01, two galectin inhibitors, bind to terminal galactose residues in glycoprotein and reduce fibrosis in animal NASH. ${ }^{[133]}$ GR-MD-02 has favorable

Table 3: Active clinical trials in the clinical trials.gov on anti-fibrotic treatments

\begin{tabular}{|c|c|c|c|c|c|}
\hline Clinicaltrials.gov & Drug & Phase & Disease & Target sample size & Status \\
\hline NCT01965418 & Fufang Biejia Ruangan & 4 & Chronic hepatitis B & 100 & Recruiting \\
\hline NCT02241616 & $\begin{array}{c}\text { Entecavir + Fuzheng Huayu + } \\
\text { TCM Granule }\end{array}$ & 4 & Chronic hepatitis B & 350 & Recruiting \\
\hline NCT00956098 & Oltipraz & 2 & Chronic hepatitis B or C & 81 & Completed \\
\hline $\begin{array}{l}\text { NCT02138253 } \\
\text { (POLT-HCV-SVR) }\end{array}$ & IDN-6556 & 2 & Chronic hepatitis C & 60 & Ongoing, finished recruitment \\
\hline NCT02744105 & Dietary Supplement: Spirulina & N/A & $\begin{array}{l}\text { Chronic hepatitis C (in } \\
\text { beta-thalassemia) }\end{array}$ & 60 & Ongoing, finished recruitment \\
\hline NCT02217475 & Cenicriviroc & 2 & NASH fibrosis & 200 & Ongoing, finished recruitment \\
\hline NCT03059446 & Cenicriviroc & 2 & NASH fibrosis & 200 & Recruiting by invitation \\
\hline $\begin{array}{l}\text { NCT03028740 } \\
\text { (AURORA) }\end{array}$ & Cenicriviroc & 3 & NASH fibrosis & 2000 & Recruiting \\
\hline NCT02530138 & Synbiotic & $2 / 3$ & NASH fibrosis & 42 & Recruiting \\
\hline NCT02686762 & Emricasan & 2 & NASH fibrosis & 330 & Recruiting \\
\hline $\begin{array}{l}\text { NCT02704403 } \\
\text { (RESOLVE-IT) }\end{array}$ & Elafibranor & 3 & NASH fibrosis & 2000 & Recruiting \\
\hline $\begin{array}{l}\text { NCT02548351 } \\
\text { (REGENERATE) }\end{array}$ & Obeticholic Acid & 3 & NASH fibrosis & 2000 & Recruiting \\
\hline $\begin{array}{l}\text { NCT03053050 } \\
\text { (STELLAR 3) }\end{array}$ & Selonsertib & 3 & NASH advanced fibrosis & 800 & Recruiting \\
\hline $\begin{array}{l}\text { NCT03053063 } \\
\text { (STELLAR 4) }\end{array}$ & Selonsertib & 3 & NASH cirrhosis & 800 & Recruiting \\
\hline NCT01899859 & GR-MD-02 & 1 & NASH cirrhosis & 31 & Completed \\
\hline NCT02462967 & GR-MD-02 & 2 & NASH cirrhosis & 156 & Ongoing, finished recruitme \\
\hline NCT02806011 & Livercellgram & 2 & Alcoholic cirrhosis & 50 & Recruiting by invitation \\
\hline NCT01452308 & Simtuzumab & $2 a$ & Any & 20 & Completed \\
\hline
\end{tabular}

NASH: non-alcoholic steatohepatitis 
safety profile in a phase I study in NASH patients with advanced fibrosis and is now under investigation in patients with NASH cirrhosis (ClinicalTrials.gov Identifier NCT01899859 and NCT02462967; Table 3). The pharmaceutical company is going to present the data from this Phase 2 clinical trial by early December 2017. ${ }^{[134]}$

\section{Other liver diseases}

Ursodeoxycholic acid (UDCA) was found to reduced serum ALT, GGT and PIIIP in an early study. ${ }^{[135]}$ Candesartan, an angiotensin receptor blocking agent, together with UDCA, when compared to UDCA alone for 6 months, induced more significant improvement of fibrosis in histological and quantitative measurements in patient with compensated alcoholic liver disease. ${ }^{[136]}$ UDCA combined with budesonide, but not UCDA alone, led to fibrosis regression in patients with primary biliary cholangitis (PBC, previously known as primary biliary cirrhosis). Obeticholic acid (OCA) is a semisynthetic 6-ethyl analogue of the endogenous bile acid chenodeoxycholic acid (CDCA) that is 100 times more potent than CDCA as a Farnesoid $X$ receptor (FXR) activator. OCA has been shown to have anticholestatic, anti-inflammatory and antifibrotic effects. ${ }^{[137]}$ OCA is found to be effective to improve liver biochemistries in a Phase 3 trial. ${ }^{[138]}$

\section{Specific anti-fibrotic treatment targets}

\section{Direct downregulation of hepatic stellate cell}

Hepatic stellate cells (HSC) are the main collagenproducing cells in the liver and their activation promotes liver fibrosis. Targeting HSC is a popular strategy for treating liver fibrosis. ${ }^{[139]}$ Liver fibrosis can be reversed via a few mechanisms, which include inhibition of HSC activation; promotion of HSC phenotypic conversion; immune clearance of HSC; promotion of HSC apoptosis; induction HSC senescence. ${ }^{[140]}$ Several drugs have been tested to down-regulating HSC activation, which include a few antioxidants (e.g. namely vitamin E, phosphatidylcholine, silymarin, resveratrol), gamma interferon, peroxisome proliferator-activated receptor gamma (PPAR-ү) agonists (e.g. pioglitazone), endothelin receptor antagonists, histone deacetylase (HDAC) inhibitors etc. ${ }^{[139]}$ Yet none of these agents has been approved as anti-fibrotic agents.

Several novel targets have been identified for the treatment of liver fibrosis through suppression of HSC activation. Interleukin (IL)-30 attenuates hepatic fibrosis by inducing natural killer group 2D (NKG2D)/ ribonucleic acid export 1 crosstalk between activated HSCs and natural killer T cells and is therefore an ideal therapy for liver fibrosis. Hydrogen peroxide-inducible clone-5 (Hic-5), a transforming growth factor (TGF)- $\beta 1$-inducible focal adhesion protein, facilitates cell proliferation, ECM expansion and vascular restoration and restructuring. ${ }^{[141]}$ Hic-5 expression also plays a critical role in attenuating fibrosis by enhancing TGF$\beta 1$-induced small mother against decapentaplegic (Smad)2 phosphorylation via the downregulation of Smad7 in both human and mouse activated HSCs. ${ }^{[142]}$

Although several drugs show potent anti-fibrotic activities in experimental models of hepatic fibrosis, there is presently no effective pharmaceutical intervention specifically approved for the treatment of liver fibrosis. Targeted delivery systems that bind specifically to receptors solely expressed on activated HSCs or trans-differentiated MFBs are essential to increase treatment efficacy as well as to reduce adverse effects. The applicability and efficacy of sequestering molecules, selective protein carriers, lipid-based drug vehicles, viral vectors, transcriptional targeting approaches, therapeutic liver- and HSCspecific nanoparticles, and miRNA-based strategies are potential and promising treatment strategies. ${ }^{[143]}$

\section{Collagen synthesis inhibitors}

Continuous accumulation of extracellular matrix (ECM) extremely rich in collagen I and III in response to liver injury leads to scar deposition and liver fibrosis. ${ }^{[144]}$ Activated HSCs are indeed a major source of collagen in the liver and can abundantly secrete ECM proteins, tissue inhibitors of metalloproteinases, and matrix metalloproteinases (MMPs) that elicit liver architecture remodeling. ${ }^{[145]}$ Apart from modulating HSC, there are some therapeutic agents directly targeting collagen synthesis.

Halofuginone is an analog of febrifugine - an alkaloid originally isolated from the plant Dichroa febrifuga. ${ }^{[146]}$ Animal model with established liver fibrosis halofuginone elicited reductions in the levels of collagen, collagen al gene expression, and $\alpha$-smoothmuscle-positive cells, and even complete resolution of liver fibrosis. ${ }^{[147]}$ Regeneration of the liver, which was blocked in rats with established fibrosis, occurred at an almost normal rate in halofuginone-treated rats. ${ }^{[148]}$ Nonetheless, there has not been a clinical study specifically that use halofuginone to treat liver fibrosis in human.

\section{TGF- $\beta$ antagonists}

TGF- $\beta 1$ is the key pro-fibrogenic cytokine involved in liver fibrosis, as it regulates the production and deposition of ECM. ${ }^{[149,150]}$ There are several approaches to interfere with TGF- $\beta$ signaling. TGF- $\beta$ expression can be down-regulated by applying anti-sense oligonucleotide mRNA. A targeted blocking of a specific 
isoform of TGF- $\beta$ by means of monoclonal antibodies is also feasible. Activation of TGF- $\beta$ receptors can be inhibited by the use of specific inhibitors, thereby halting downstream signaling. Local activation of TGF- $\beta$ induced by $\alpha v \beta 6$ integrin and by tropomyosinrelated kinase (TSP)-1 can be prevented. [151] The amino acid sequence Leu-Ser-Lys-Leu (LSKL) naturally occurs in the region of the amino terminus of the LAP and that it can hamper the activation of latent TGF- $\beta$ by TSP-1 through competitive inhibition. ${ }^{[152]}$ LSKL peptides significantly decrease $\mathrm{DMN}$-induced liver atrophy and fibrosis in an animal model.. ${ }^{[153]}$ Yet LSKL has not been developed clinically. More recently nanoconjugate siRNA against TGF- $\beta 1$ equipped with an $\mathrm{N}$-acetylglucosamin targeting moiety intending to reach HSCs via desmin was reported to colocalize with HSCs and to reduce liver fibrosis. ${ }^{[154]}$

\section{Connective tissue growth factor inhibitor}

CTGF is a mediator of ECM accumulation and coordinates a late common pathway to fibrosis. ${ }^{[155]}$ Blocking connective tissue growth factor (CTGF) activity reduces liver fibrosis and preserves liver function. ${ }^{[156]}$ FG-3019 is a recombinant human antiCTGF monoclonal immunoglobulin $G$ antibody. FG3019 reduces collagen deposition in nonclinical models of liver. FG-3019 was tested in CHB patients in a Phase 2 randomized trial; unfortunately the study terminated due to an unexpected prominent effect of entecavir alone in this patient population. ${ }^{[157]}$

\section{CONCLUSION}

With the wide applicability of non-invasive assessments of liver fibrosis, the management of 2 billion patients with chronic liver diseases worldwide has been revolutionized. While liver biopsy examination still has an important role in the diagnostic process, noninvasive assessments including transient elastography and serum biomarkers have high accurate to diagnose advanced fibrosis and cirrhosis. Transient elastography and serum biomarkers can be used alone or in combination, either simultaneously or in a stepwise approach. Meanwhile, ARFI and SWE are effective for staging liver fibrosis, especially when ultrasound is the first imaging tool for assessment of diffuse liver disease. Treating underlying chronic liver diseases is still the cornerstone of liver fibrosis regression. Potent antiviral treatments for chronic viral hepatitis lead to regression of liver fibrosis and even cirrhosis in majority of patients. Numerous ongoing clinical trials in NAFLD patients will bring us treatment to treat NASH fibrosis and cirrhosis soon. Plentiful therapeutic agents specifically targeting the fibrogenesis pathways, in particulars HSC and TGF- $\beta 1$ work well in animal models. We look forward to assess these agents in human and hopefully they can modify the natural history of chronic liver diseases, and more importantly, to improve patient outcome in the near future.

\section{DECLARATIONS}

\section{Authors' contributions}

Drafting of the manuscript: J.Y.K. Cheng, G.L.H. Wong Critical revision of the manuscript for important intellectual content: J.Y.K. Cheng, G.L.H. Wong

\section{Financial support and sponsorship}

None.

\section{Conflicts of interest}

Grace L.H. Wong has served as an advisory committee member for Gilead Sciences. She has also served as a speaker for Abbott, Abbvie, Bristol-Myers Squibb, Echosens, Furui, Gilead Sciences, Janssen and Roche.

\section{Patient consent}

Not applicable.

\section{Ethics approval}

Not applicable.

\section{REFERENCES}

1. Weiskirchen R, Tacke F. Liver fibrosis: from pathogenesis to novel therapies. Dig Dis 2016;34:410-22.

2. Pinter M, Trauner M, Peck-Radosavljevic M, Sieghart W. Cancer and liver cirrhosis: implications on prognosis and management. ESMO Open 2016; 1:e00042.

3. European Association for the Study of the Liver. EASL 2017 Clinical Practice Guidelines on the management of hepatitis B virus infection. J Hepatol 2017;67:370-98.

4. Sarin SK, Kumar M, Lau GK, Abbas Z, Chan HL, Chen CJ, Chen DS, Chen HL, Chen PJ, Chien RN, Dokmeci AK, Gane E, Hou JL, Jafri W, Jia J, Kim JH, Lai CL, Lee HC, Lim SG, Liu CJ, Locarnini S, Al Mahtab M, Mohamed R, Omata M, Park J, Piratvisuth T, Sharma BC, Sollano J, Wang FS, Wei L, Yuen MF, Zheng SS, Kao JH. AsianPacific clinical practice guidelines on the management of hepatitis B: a 2015 update. Hepatol Int 2016;10:1-98.

5. Ellis EL, Mann DA. Clinical evidence for the regression of liver fibrosis. J Hepatol 2012;56:1171-80.

6. Rockey DC, Caldwell SH, Goodman ZD, Nelson RC, Smith AD; American Association for the Study of Liver Diseases. Liver biopsy. Hepatology 2009;49:1017-44.

7. Amarapurkar D, Amarapurkar A. Indications of liver biopsy in the era of noninvasive assessment of liver fibrosis. J Clin Exp Hepatol 2015;5:314-9.

8. Goodman ZD. Grading and staging systems for inflammation and fibrosis in chronic liver diseases. J Hepatol 2007;47:598-607.

9. Karanjia RN, Crossey MM, Cox IJ, Fye HK, Njie R, Goldin RD, Taylor-Robinson SD. Hepatic steatosis and fibrosis: non-invasive assessment. World J Gastroenterol 2016;22:9880-97.

10. Wong GL, Wong VW, Choi PC, Chan AW, Chum RH, Chan HK, Lau 
KK, Chim AM, Yiu KK, Chan FK, Sung JJ, Chan HL. Assessment of fibrosis by transient elastography compared with liver biopsy and morphometry in chronic liver diseases. Clin Gastroenterol Hepatol 2008;6:1027-35.

11. Xu S, Wang Y, Tai DC, Wang S, Cheng CL, Peng Q, Yan J, Chen Y, Sun J, Liang X, Zhu Y, Rajapakse JC, Welsch RE, So PT, Wee A, Hou J, Yu H. qFibrosis: a fully-quantitative innovative method incorporating histological features to facilitate accurate fibrosis scoring in animal model and chronic hepatitis B patients. $J$ Hepatol 2014;61:260-9.

12. Nalbantoglu IL, Brunt EM. Role of liver biopsy in nonalcoholic fatty liver disease. World J Gastroenterol 2014;20:9026-37.

13. Misdraji J, Lauwers GY, Irving JA, Batts KP, Young RH. Appendiceal or cecal endometriosis with intestinal metaplasia: a potential mimic of appendiceal mucinous neoplasms. Am J Surg Pathol 2014;38:698705.

14. Vuppalanchi R, Unalp A, Van Natta ML, Cummings OW, Sandrasegaran KE, Hameed T, Tonascia J, Chalasani N. Effects of liver biopsy sample length and number of readings on sampling variability in nonalcoholic fatty liver disease. Clin Gastroenterol Hepatol 2009;7:481-6.

15. Machado NN, Jackson T, Ladhani HA, Marks JM. Managing complications in endoscopic procedures: bleeding from a biopsy site. Minerva Chir 2017;72:36-43.

16. Kose S, Ersan G, Tatar B, Adar P, Sengel BE. Evaluation of percutaneous liver biopsy complications in patients with chronic viral hepatitis. Eurasian J Med 2015;47:161-4.

17. Claudi C, Henschel M, Vogel J, Schepke M, Biecker E. Fulminant sepsis after liver biopsy: a long forgotten complication? World J Clin Cases 2013;1:41-3.

18. Tchatalbachev VV, Kirkpatrick DL, Duff DJ, Travis MD. Seeding of the rectus sheath with hepatocellular carcinoma after image guided percutaneous liver biopsy using coaxial biopsy needle system. $J$ Radiol Case Rep 2015;9:18-25.

19. Wong GL. Update of liver fibrosis and steatosis with transient elastography (Fibroscan). Gastroenterol Rep (Oxf) 2013;1:19-26.

20. Wong VW, Chan HL. Transient elastography. J Gastroenterol Hepatol 2010;25:1726-31.

21. Barr RG, Ferraioli G, Palmeri ML, Goodman ZD, Garcia-Tsao G, Rubin J, Garra B, Myers RP, Wilson SR, Rubens D, Levine D. Elastography assessment of liver fibrosis: Society of Radiologists in Ultrasound Consensus Conference Statement. Radiology 2015;276:845-61.

22. Wong GL. Transient elastography: kill two birds with one stone? World J Hepatol 2013;5:264-74.

23. Puigvehi M, Broquetas T, Coll S, Garcia-Retortillo M, Canete N, Fernandez R, Gimeno J, Sanchez J, Bory F, Pedro-Botet J, Sola R, Carrion JA. Impact of anthropometric features on the applicability and accuracy of FibroScan $®(\mathrm{M}$ and XL) in overweight/obese patients. $J$ Gastroenterol Hepatol 2017; doi: 10.1111/jgh.13762.

24. Wong GL, Wong VW, Chim AM, Yiu KK, Chu SH, Li MK, Chan HL. Factors associated with unreliable liver stiffness measurement and its failure with transient elastography in the Chinese population. $J$ Gastroenterol Hepatol 2011;26:300-5.

25. Wong GL, Wong VW, Choi PC, Chan AW, Chim AM, Yiu KK, Chan FK, Sung JJ, Chan HL. Increased liver stiffness measurement by transient elastography in severe acute exacerbation of chronic hepatitis B. J Gastroenterol Hepatol 2009;24:1002-7.

26. Wong GL, Wong VW, Choi PC, Chan AW, Chim AM, Yiu KK, Chu SH, Chan FK, Sung JJ, Chan HL. On-treatment monitoring of liver fibrosis with transient elastography in chronic hepatitis B patients. Antivir Ther 2011;16:165-72.

27. D’Ambrosio R, Aghemo A, Fraquelli M, Rumi MG, Donato MF,
Paradis V, Bedossa P, Colombo M. The diagnostic accuracy of Fibroscan for cirrhosis is influenced by liver morphometry in HCV patients with a sustained virological response. J Hepatol 2013;59:2516.

28. D’Onofrio M, Crosara S, De Robertis R, Canestrini S, Demozzi E, Gallotti A, Pozzi Mucelli R. Acoustic radiation force impulse of the liver. World J Gastroenterol 2013;19:4841-9.

29. Bota S, Herkner H, Sporea I, Salzl P, Sirli R, Neghina AM, PeckRadosavljevic M. Meta-analysis: ARFI elastography versus transient elastography for the evaluation of liver fibrosis. Liver Int 2013;33:1138-47.

30. Takahashi H, Ono N, Eguchi Y, Eguchi T, Kitajima Y, Kawaguchi Y, Nakashita S, Ozaki I, Mizuta T, Toda S, Kudo S, Miyoshi A, Miyazaki K, Fujimoto K. Evaluation of acoustic radiation force impulse elastography for fibrosis staging of chronic liver disease: a pilot study. Liver Int 2010;30:538-45.

31. Tachi Y, Hirai T, Kojima Y, Miyata A, Ohara K, Ishizu Y, Honda T, Kuzuya T, Hayashi K, Ishigami M, Goto H. Liver stiffness measurement using acoustic radiation force impulse elastography in hepatitis $\mathrm{C}$ virus-infected patients with a sustained virological response. Aliment Pharmacol Ther 2016;44:346-55.

32. Attia D, Bantel H, Lenzen H, Manns MP, Gebel MJ, Potthoff A. Liver stiffness measurement using acoustic radiation force impulse elastography in overweight and obese patients. Aliment Pharmacol Ther 2016;44:366-79.

33. Lin YH, Yeh ML, Huang CI, Yang JF, Liang PC, Huang CF, Dai CY, Lin ZY, Chen SC, Huang JF, Yu ML, Chuang WL. The performance of acoustic radiation force impulse imaging in predicting liver fibrosis in chronic liver diseases. Kaohsiung J Med Sci 2016;32:362-6.

34. Goertz RS, Sturm J, Zopf S, Wildner D, Neurath MF, Strobel D. Outcome analysis of liver stiffness by ARFI (acoustic radiation force impulse) elastometry in patients with chronic viral hepatitis B and C. Clin Radiol 2014;69:275-9.

35. Franchi-Abella S, Corno L, Gonzales E, Antoni G, Fabre M, Ducot B, Pariente D, Gennisson JL, Tanter M, Correas JM. Feasibility and diagnostic accuracy of supersonic shear-wave elastography for the assessment of liver stiffness and liver fibrosis in children: a pilot study of 96 patients. Radiology 2016;278:554-62.

36. Zhao H, Chen J, Meixner DD, Xie H, Shamdasani V, Zhou S, Robert JL, Urban MW, Sanchez W, Callstrom MR, Ehman RL, Greenleaf JF, Chen S. Noninvasive assessment of liver fibrosis using ultrasoundbased shear wave measurement and comparison to magnetic resonance elastography. J Ultrasound Med 2014;33:1597-604.

37. Yegin EG, Yegin K, Karatay E, Kombak EF, Tuney D, Ataizi-Celikel C, Ozdogan OC. Quantitative assessment of liver fibrosis by digital image analysis: relationship to Ishak staging and elasticity by shearwave elastography. J Dig Dis 2015;16:217-27.

38. Jiang T, Tian G, Zhao Q, Kong D, Cheng C, Zhong L, Li L. Diagnostic accuracy of 2D-shear wave elastography for liver fibrosis severity: a meta-analysis. PLoS One 2016;11:e0157219.

39. Dietrich CF, Bamber J, Berzigotti A, Bota S, Cantisani V, Castera L, Cosgrove D, Ferraioli G, Friedrich-Rust M, Gilja OH, Goertz RS, Karlas T, de Knegt R, de Ledinghen V, Piscaglia F, Procopet B, Saftoiu A, Sidhu PS, Sporea I, Thiele M. EFSUMB guidelines and recommendations on the clinical use of liver ultrasound elastography, update 2017 (long version). Ultraschall Med 2017; doi: 10.1055/s0043-103952.

40. Piscaglia F, Salvatore V, Mulazzani L, Cantisani V, Schiavone C. Ultrasound shear wave elastography for liver disease. A critical appraisal of the many actors on the stage. Ultraschall Med 2016;37:15.

41. Wagner M, Besa C, Bou Ayache J, Yasar TK, Bane O, Fung M, Ehman RL, Taouli B. Magnetic resonance elastography of the liver: 
qualitative and quantitative comparison of gradient echo and spin echo echoplanar imaging sequences. Invest Radiol 2016;51:575-81.

42. Huwart L, van Beers BE. MR elastography. Gastroenterol Clin Biol 2008;32:68-72.

43. Sande JA, Verjee S, Vinayak S, Amersi F, Ghesani M. Ultrasound shear wave elastography and liver fibrosis: a prospective multicenter study. World J Hepatol 2017;9:38-47.

44. Dulai PS, Sirlin CB, Loomba R. MRI and MRE for non-invasive quantitative assessment of hepatic steatosis and fibrosis in NAFLD and NASH: clinical trials to clinical practice. J Hepatol 2016;65:100616.

45. Wai CT, Greenson JK, Fontana RJ, Kalbfleisch JD, Marrero JA, Conjeevaram HS, Lok AS. A simple noninvasive index can predict both significant fibrosis and cirrhosis in patients with chronic hepatitis C. Hepatology 2003;38:518-26.

46. Forns X, Ampurdanes S, Llovet JM, Aponte J, Quinto L, MartinezBauer E, Bruguera M, Sanchez-Tapias JM, Rodes J. Identification of chronic hepatitis $\mathrm{C}$ patients without hepatic fibrosis by a simple predictive model. Hepatology 2002;36:986-92.

47. Vallet-Pichard A, Mallet V, Nalpas B, Verkarre V, Nalpas A, Dhalluin-Venier V, Fontaine H, Pol S. FIB-4: an inexpensive and accurate marker of fibrosis in HCV infection. comparison with liver biopsy and fibrotest. Hepatology 2007;46:32-6.

48. Koda M, Matunaga Y, Kawakami M, Kishimoto Y, Suou T, Murawaki Y. FibroIndex, a practical index for predicting significant fibrosis in patients with chronic hepatitis C. Hepatology 2007;45:297-306.

49. Hui AY, Chan HL, Wong VW, Liew CT, Chim AM, Chan FK, Sung JJ. Identification of chronic hepatitis B patients without significant liver fibrosis by a simple noninvasive predictive model. Am J Gastroenterol 2005;100:616-23.

50. Angulo P, Hui JM, Marchesini G, Bugianesi E, George J, Farrell GC, Enders F, Saksena S, Burt AD, Bida JP, Lindor K, Sanderson SO, Lenzi M, Adams LA, Kench J, Therneau TM, Day CP. The NAFLD fibrosis score: a noninvasive system that identifies liver fibrosis in patients with NAFLD. Hepatology 2007;45:846-54.

51. Ratziu V, Giral P, Charlotte F, Bruckert E, Thibault V, Theodorou I, Khalil L, Turpin G, Opolon P, Poynard T. Liver fibrosis in overweight patients. Gastroenterology 2000;118:1117-23.

52. Teshale E, Lu M, Rupp LB, Holmberg SD, Moorman AC, Spradling P, Vijayadeva V, Boscarino JA, Schmidt MA, Gordon SC, Investigators CH. APRI and FIB-4 are good predictors of the stage of liver fibrosis in chronic hepatitis B: the Chronic Hepatitis Cohort Study (CHeCS). $J$ Viral Hepat 2014;21:917-20.

53. Kim WR, Berg T, Asselah T, Flisiak R, Fung S, Gordon SC, Janssen HL, Lampertico P, Lau D, Bornstein JD, Schall RE, Dinh P, Yee LJ, Martins EB, Lim SG, Loomba R, Petersen J, Buti M, Marcellin P. Evaluation of APRI and FIB-4 scoring systems for non-invasive assessment of hepatic fibrosis in chronic hepatitis B patients. $J$ Hepatol 2016;64:773-80.

54. Imbert-Bismut F, Ratziu V, Pieroni L, Charlotte F, Benhamou Y, Poynard T, Group M. Biochemical markers of liver fibrosis in patients with hepatitis $\mathrm{C}$ virus infection: a prospective study. Lancet 2001;357:1069-75.

55. Halfon P, Munteanu M, Poynard T. FibroTest-ActiTest as a noninvasive marker of liver fibrosis. Gastroenterol Clin Biol 2008;32:2239.

56. European Association for Study of L, Asociacion Latinoamericana para el Estudio del H. EASL-ALEH Clinical Practice Guidelines: Non-invasive tests for evaluation of liver disease severity and prognosis. J Hepatol 2015;63:237-64.

57. European Association for the Study of the L, European Association for the Study of D, European Association for the Study of O. EASLEASD-EASO Clinical Practice Guidelines for the management of non-alcoholic fatty liver disease. J Hepatol 2016;64:1388-402.

58. Panel AIHG. Hepatitis C guidance: AASLD-IDSA recommendations for testing, managing, and treating adults infected with hepatitis $\mathrm{C}$ virus. Hepatology 2015;62:932-54.

59. Poynard T, Munteanu M, Deckmyn O, Ngo Y, Drane F, Messous D, Castille JM, Housset C, Ratziu V, Imbert-Bismut F. Applicability and precautions of use of liver injury biomarker FibroTest. A reappraisal at 7 years of age. BMC Gastroenterol 2011;11:39.

60. Poynard T, Lassailly G, Diaz E, Clement K, Caiazzo R, Tordjman J, Munteanu M, Perazzo H, Demol B, Callafe R, Pattou F, Charlotte F, Bedossa P, Mathurin P, Ratziu V, consortium F. Performance of biomarkers FibroTest, ActiTest, SteatoTest, and NashTest in patients with severe obesity: meta analysis of individual patient data. PLoS One 2012; 7:e30325.

61. Salkic NN, Jovanovic P, Hauser G, Brcic M. FibroTest/Fibrosure for significant liver fibrosis and cirrhosis in chronic hepatitis B: a metaanalysis. Am J Gastroenterol 2014;109:796-809.

62. Cales P, Boursier J, Oberti F, Hubert I, Gallois Y, Rousselet MC, Dib N, Moal V, Macchi L, Chevailler A, Michalak S, Hunault G, Chaigneau J, Sawadogo A, Lunel F. FibroMeters: a family of blood tests for liver fibrosis. Gastroenterol Clin Biol 2008;32:40-51.

63. Cales P, de Ledinghen V, Halfon P, Bacq Y, Leroy V, Boursier J, Foucher J, Bourliere M, de Muret A, Sturm N, Hunault G, Oberti F. Evaluating the accuracy and increasing the reliable diagnosis rate of blood tests for liver fibrosis in chronic hepatitis C. Liver Int 2008;28:1352-62.

64. Cales P, Boursier J, Bertrais S, Oberti F, Gallois Y, Fouchard-Hubert I, Dib N, Zarski JP, Rousselet MC; multicentric groups. Optimization and robustness of blood tests for liver fibrosis and cirrhosis. Clin Biochem 2010;43:1315-22.

65. Boursier J, de Ledinghen V, Zarski JP, Rousselet MC, Sturm N, Foucher J, Leroy V, Fouchard-Hubert I, Bertrais S, Gallois Y, Oberti F, Dib N, Cales P. A new combination of blood test and fibroscan for accurate non-invasive diagnosis of liver fibrosis stages in chronic hepatitis C. Am J Gastroenterol 2011;106:1255-63.

66. Loong TC, Wei JL, Leung JC, Wong GL, Shu SS, Chim AM, Chan AW, Choi PC, Tse YK, Chan HL, Wong VW. Application of the combined FibroMeter vibration-controlled transient elastography algorithm in Chinese patients with non-alcoholic fatty liver disease. $J$ Gastroenterol Hepatol 2017;32:1363-9.

67. Armutcu F, Akyol S, Ucar F, Erdogan S, Akyol O. Markers in nonalcoholic steatohepatitis. Adv Clin Chem 2013;61:67-125.

68. Kaswala DH, Lai M, Afdhal NH. Fibrosis assessment in nonalcoholic fatty liver disease (NAFLD) in 2016. Dig Dis Sci 2016;61:1356-64.

69. Wong GL, Chan HL, Choi PC, Chan AW, Yu Z, Lai JW, Chan HY, Wong VW. Non-invasive algorithm of enhanced liver fibrosis and liver stiffness measurement with transient elastography for advanced liver fibrosis in chronic hepatitis B. Aliment Pharmacol Ther 2014;39:197208.

70. Parkes J, Roderick P, Harris S, Day C, Mutimer D, Collier J, Lombard M, Alexander G, Ramage J, Dusheiko G, Wheatley M, Gough C, Burt A, Rosenberg W. Enhanced liver fibrosis test can predict clinical outcomes in patients with chronic liver disease. Gut 2010;59:1245-51.

71. Puigvehi M, Hernandez J, Broquetas T, Coll S, Garcia-Retortillo M, Canete N, Gimenez MD, Garcia M, Bory F, Salvado M, Sola $\mathrm{R}$, Carrion JA. Diagnostic accuracy of the enhanced liver fibrosis (ELF®) score using HCV-infected serum samples cryopreserved for up to 25 years. PLoS One 2016;11:e0164883.

72. Wahl K, Rosenberg W, Vaske B, Manns MP, Schulze-Osthoff K, Bahr MJ, Bantel H. Biopsy-controlled liver fibrosis staging using the enhanced liver fibrosis (ELF) score compared to transient elastography. PLoS One 2012; 7:e51906.

73. Xie Q, Zhou X, Huang P, Wei J, Wang W, Zheng S. The performance 
of enhanced liver fibrosis (ELF) test for the staging of liver fibrosis: a meta-analysis. PLoS One 2014;9:e92772.

74. Lichtinghagen R, Pietsch D, Bantel H, Manns MP, Brand K, Bahr MJ. The Enhanced Liver Fibrosis (ELF) score: normal values, influence factors and proposed cut-off values. J Hepatol 2013;59:236-42.

75. Swanson S, Ma Y, Scherzer R, Huhn G, French AL, Plankey MW, Grunfeld C, Rosenberg WM, Peters MG, Tien PC. Association of HIV, hepatitis $\mathrm{C}$ virus, and liver fibrosis severity with the enhanced liver fibrosis score. J Infect Dis 2016;213:1079-86.

76. Toshima T, Shirabe K, Ikegami T, Yoshizumi T, Kuno A, Togayachi A, Gotoh M, Narimatsu H, Korenaga M, Mizokami M, Nishie A, Aishima S, Maehara Y. A novel serum marker, glycosylated Wisteria floribunda agglutinin-positive Mac-2 binding protein (WFA(+)M2BP), for assessing liver fibrosis. J Gastroenterol 2015;50:76-84.

77. Zou X, Zhu MY, Yu DM, Li W, Zhang DH, Lu FJ, Gong QM, Liu F, Jiang JH, Zheng MH, Kuno A, Narimatsu H, Zhang Y, Zhang XX. Serum WFA+ -M2BP levels for evaluation of early stages of liver fibrosis in patients with chronic hepatitis B virus infection. Liver Int 2017;37:35-44.

78. Tao H, Yang JJ, Shi KH, Huang C, Zhang L, Lv XW, Li J. The significance of YKL-40 protein in liver fibrosis. Inflamm Res 2014;63:249-54.

79. Kumagai E, Mano Y, Yoshio S, Shoji H, Sugiyama M, Korenaga M, Ishida T, Arai T, Itokawa N, Atsukawa M, Hyogo H, Chayama K, Ohashi T, Ito K, Yoneda M, Kawaguchi T, Torimura T, Nozaki Y, Watanabe S, Mizokami M, Kanto T. Serum YKL-40 as a marker of liver fibrosis in patients with non-alcoholic fatty liver disease. Sci Rep 2016;6:35282.

80. Trembling PM, Lampertico P, Parkes J, Tanwar S, Vigano M, Facchetti F, Colombo M, Rosenberg WM. Performance of Enhanced Liver Fibrosis test and comparison with transient elastography in the identification of liver fibrosis in patients with chronic hepatitis B infection. J Viral Hepat 2014;21:430-8.

81. Wong GL, Chan HL, Yu Z, Wong CK, Leung C, Ho PP, Chan CY, Chung VC, Chan ZC, Tse YK, Chim AM, Lau TK, Chan HY, Tse CH, Wong VW. Noninvasive assessments of liver fibrosis with transient elastography and Hui index predict survival in patients with chronic hepatitis B. J Gastroenterol Hepatol 2015;30:582-90.

82. Wong GL, Wong VW, Choi PC, Chan AW, Chan HL. Development of a non-invasive algorithm with transient elastography (Fibroscan) and serum test formula for advanced liver fibrosis in chronic hepatitis B. Aliment Pharmacol Ther 2010;31:1095-103.

83. Crisan D, Radu C, Lupsor M, Sparchez Z, Grigorescu MD, Grigorescu M. Two or more synchronous combination of noninvasive tests to increase accuracy of liver fibrosis assessement in chronic hepatitis $\mathrm{C}$; results from a cohort of 446 patients. Hepat Mon 2012;12:177-84.

84. Poynard T, de Ledinghen V, Zarski JP, Stanciu C, Munteanu M, Vergniol J, France J, Trifan A, Lenaour G, Vaillant JC, Ratziu V, Charlotte F; Fibrosis-TAGS group. Performances of Elasto-FibroTest((R)), a combination between FibroTest((R)) and liver stiffness measurements for assessing the stage of liver fibrosis in patients with chronic hepatitis C. Clin Res Hepatol Gastroenterol 2012;36:455-63.

85. Zhang CY, Yuan WG, He P, Lei JH, Wang CX. Liver fibrosis and hepatic stellate cells: Etiology, pathological hallmarks and therapeutic targets. World J Gastroenterol 2016;22:10512-22.

86. Sun XL, Liang LW, Cao H, Men Q, Hou KZ, Chen Z, Zhao YE. Liver reserve function assessment by acoustic radiation force impulse imaging. World J Gastroenterol 2015;21:9648-55.

87. Morisaka H, Motosugi U, Ichikawa S, Sano K, Ichikawa T, Enomoto N. Association of splenic MR elastographic findings with gastroesophageal varices in patients with chronic liver disease. $J$ Magn Reson Imaging 2015;41:117-24.

88. Wong GL, Kwok R, Chan HL, Tang SP, Lee E, Lam TC, Lau TW,
Ma TM, Wong BC, Wong VW. Measuring spleen stiffness to predict varices in chronic hepatitis B cirrhotic patients with or without receiving non-selective beta-blockers. J Dig Dis 2016;17:538-46.

89. Wong GL, Kwok R, Hui AJ, Chan HL, Wong VW. A new screening strategy for varices based on liver and spleen stiffness measurement (LSSM) in cirrhotic patients: a randomized controlled trial. J Hepatol 2017;66:S79.

90. Pang Q, Zhang JY, Xu XS, Song SD, Chen W, Zhou YY, Miao RC, Qu K, Liu SS, Dong YF, Liu C. The prognostic values of 12 cirrhosis-relative noninvasive models in patients with hepatocellular carcinoma. Scand J Clin Lab Invest 2015;75:73-84.

91. Wong JS, Wong GL, Chan AW, Wong VW, Cheung YS, Chong CC, Wong J, Lee KF, Chan HL, Lai PB. Liver stiffness measurement by transient elastography as a predictor on posthepatectomy outcomes. Ann Surg 2013;257:922-8.

92. de Ledinghen V, Vergniol J, Barthe C, Foucher J, Chermak F, Le Bail $\mathrm{B}$, Merrouche W, Bernard PH. Non-invasive tests for fibrosis and liver stiffness predict 5-year survival of patients chronically infected with hepatitis B virus. Aliment Pharmacol Ther 2013;37:979-88.

93. Vergniol J, Foucher J, Terrebonne E, Bernard PH, le Bail B, Merrouche W, Couzigou P, de Ledinghen V. Noninvasive tests for fibrosis and liver stiffness predict 5-year outcomes of patients with chronic hepatitis C. Gastroenterology 2011;140:1970-9, 9 e1-3.

94. Boursier J, Brochard C, Bertrais S, Michalak S, Gallois Y, FouchardHubert I, Oberti F, Rousselet MC, Cales P. Combination of blood tests for significant fibrosis and cirrhosis improves the assessment of liver-prognosis in chronic hepatitis C. Aliment Pharmacol Ther 2014; $40: 178-88$.

95. Vesterhus M, Hov JR, Holm A, Schrumpf E, Nygard S, Godang K, Andersen IM, Naess S, Thorburn D, Saffioti F, Vatn M, Gilja OH, Lund-Johansen F, Syversveen T, Brabrand K, Pares A, Ponsioen CY, Pinzani M, Farkkila M, Moum B, Ueland T, Rosjo H, Rosenberg W, Boberg KM, Karlsen TH. Enhanced liver fibrosis score predicts transplant-free survival in primary sclerosing cholangitis. Hepatology 2015;62:188-97.

96. Peters MG, Bacchetti P, Boylan R, French AL, Tien PC, Plankey MW, Glesby MJ, Augenbraun M, Golub ET, Karim R, Parkes J, Rosenberg W. Enhanced liver fibrosis marker as a noninvasive predictor of mortality in HIV/hepatitis C virus-coinfected women from a multicenter study of women with or at risk for HIV. AIDS 2016;30:723-9.

97. Shuang-Ming T, Ping Z, Ying Q, Li-Rong C, Ping Z, Rui-Zhen L. Usefulness of acoustic radiation force impulse imaging in the differential diagnosis of benign and malignant liver lesions. Acad Radiol 2011;18:810-5.

98. Garteiser P, Doblas S, Daire JL, Wagner M, Leitao H, Vilgrain V, Sinkus R, Van Beers BE. MR elastography of liver tumours: value of viscoelastic properties for tumour characterisation. Eur Radiol 2012;22:2169-77.

99. Wong GL, Chan HL, Wong CK, Leung C, Chan CY, Ho PP, Chung VC, Chan ZC, Tse YK, Chim AM, Lau TK, Wong VW. Liver stiffness-based optimization of hepatocellular carcinoma risk score in patients with chronic hepatitis B. J Hepatol 2014;60:339-45.

100. Poynard T, Vergniol J, Ngo Y, Foucher J, Munteanu M, Merrouche W, Colombo M, Thibault V, Schiff E, Brass CA, Albrecht JK, Rudler M, Deckmyn O, Lebray P, Thabut D, Ratziu V, de Ledinghen V, FibroFrance Study G, Epic3 Study G, Bordeaux HCVSG. Staging chronic hepatitis $\mathrm{C}$ in seven categories using fibrosis biomarker (FibroTest) and transient elastography (FibroScan(R)). J Hepatol 2014;60:706-14.

101. Kim BK, Kim HS, Yoo EJ, Oh EJ, Park JY, Kim DY, Ahn SH, Han KH, Kim SU, Park YN. Risk assessment of clinical outcomes in Asian patients with chronic hepatitis B using enhanced liver fibrosis test. 
Hepatology 2014;60:1911-9.

102. Chong CC, Wong GL, Chan AW, Wong VW, Fong AK, Cheung YS, Wong J, Lee KF, Chan SL, Lai PB, Chan HL. Liver stiffness measurement predicts high-grade post-hepatectomy liver failure: a prospective cohort study. J Gastroenterol Hepatol 2017;32:506-14.

103. George SL, Bacon BR, Brunt EM, Mihindukulasuriya KL, Hoffmann J, Di Bisceglie AM. Clinical, virologic, histologic, and biochemical outcomes after successful HCV therapy: a 5-year follow-up of 150 patients. Hepatology 2009;49:729-38.

104. Marcellin P, Gane E, Buti M, Afdhal N, Sievert W, Jacobson IM, Washington MK, Germanidis G, Flaherty JF, Schall RA, Bornstein JD, Kitrinos KM, Subramanian GM, McHutchison JG, Heathcote EJ. Regression of cirrhosis during treatment with tenofovir disoproxil fumarate for chronic hepatitis B: a 5-year open-label follow-up study. Lancet 2013;381:468-75.

105. Chang TT, Liaw YF, Wu SS, Schiff E, Han KH, Lai CL, Safadi R, Lee SS, Halota W, Goodman Z, Chi YC, Zhang H, Hindes R, Iloeje $\mathrm{U}$, Beebe S, Kreter B. Long-term entecavir therapy results in the reversal of fibrosis/cirrhosis and continued histological improvement in patients with chronic hepatitis B. Hepatology 2010;52:886-93.

106. Buti M, Gane E, Aguilar Schall R, Tsai NC, Washington MK, Lee SS, Chan S, Trinh H, Flaherty JF, Kitrinos KM, Dinh P, Charuworn P, Subramanian GM, Marcellin P. Hepatic steatosis does not predict regression of liver cirrhosis in chronic hepatitis b $(\mathrm{CHB})$ patients treated with tenofovir disoproxil fumarate (TDF). $J$ Hepatol 2015;60:S294-5.

107. Wong GL, Wong VW, Choi PC, Chan AW, Chim AM, Yiu KK, Chan HY, Chan FK, Sung JJ, Chan HL. Metabolic syndrome increases the risk of liver cirrhosis in chronic hepatitis B. Gut 2009;58:111-7.

108. Yoon H, Lee JG, Yoo JH, Son MS, Kim DY, Hwang SG, Rim KS. Effects of metabolic syndrome on fibrosis in chronic viral hepatitis. Gut Liver 2013;7:469-74.

109. Wong GL, Chan HL, Yu Z, Chan AW, Choi PC, Chim AM, Chan $\mathrm{HY}$, Tse CH, Wong VW. Coincidental metabolic syndrome increases the risk of liver fibrosis progression in patients with chronic hepatitis B--a prospective cohort study with paired transient elastography examinations. Aliment Pharmacol Ther 2014;39:883-93.

110. Cheng JY, Wong VW, Tse YK, Chim AM, Chan HL, Wong GL. Metabolic syndrome increases cardiovascular events but not hepatic events and death in patients with chronic hepatitis B. Hepatology 2016;64:1507-17.

111. Wong GL, Chan HL, Yu Z, Chan HY, Tse CH, Wong VW. Liver fibrosis progression is uncommon in patients with inactive chronic hepatitis B: a prospective cohort study with paired transient elastography examination. J Gastroenterol Hepatol 2013;28:1842-8.

112. Wong GL, Chan HL, Yu Z, Chan HY, Tse CH, Wong VW. Liver fibrosis progression in chronic hepatitis B patients positive for hepatitis B e antigen: a prospective cohort study with paired transient elastography examination. J Gastroenterol Hepatol 2013;28:1762-9.

113. Shiratori Y, Imazeki F, Moriyama M, Yano M, Arakawa Y, Yokosuka O, Kuroki T, Nishiguchi S, Sata M, Yamada G, Fujiyama S, Yoshida $\mathrm{H}$, Omata M. Histologic improvement of fibrosis in patients with hepatitis $\mathrm{C}$ who have sustained response to interferon therapy. Ann Intern Med 2000;132:517-24.

114. Camma C, Di Bona D, Schepis F, Heathcote EJ, Zeuzem S, Pockros PJ, Marcellin P, Balart L, Alberti A, Craxi A. Effect of peginterferon alfa-2a on liver histology in chronic hepatitis $\mathrm{C}$ : a meta-analysis of individual patient data. Hepatology 2004;39:333-42.

115. Poynard T, McHutchison J, Manns M, Trepo C, Lindsay K, Goodman $\mathrm{Z}$, Ling $\mathrm{MH}$, Albrecht J. Impact of pegylated interferon alfa- $2 \mathrm{~b}$ and ribavirin on liver fibrosis in patients with chronic hepatitis C. Gastroenterology 2002;122:1303-13.

116. Jakobsen JC, Nielsen EE, Feinberg J, Katakam KK, Fobian K, Hauser
G, Poropat G, Djurisic S, Weiss KH, Bjelakovic M, Bjelakovic G, Klingenberg SL, Liu JP, Nikolova D, Koretz RL, Gluud C. Directacting antivirals for chronic hepatitis C. Cochrane Database Syst Rev 2017;6:CD012143.

117. Knop V, Hoppe D, Welzel T, Vermehren J, Herrmann E, Vermehren A, Friedrich-Rust M, Sarrazin C, Zeuzem S, Welker MW. Regression of fibrosis and portal hypertension in $\mathrm{HCV}$-associated cirrhosis and sustained virologic response after interferon-free antiviral therapy. $J$ Viral Hepat 2016;23:994-1002.

118. Bachofner JA, Valli PV, Kroger A, Bergamin I, Kunzler P, Baserga A, Braun D, Seifert B, Moncsek A, Fehr J, Semela D, Magenta L, Mullhaupt B, Terziroli Beretta-Piccoli B, Mertens JC. Direct antiviral agent treatment of chronic hepatitis $\mathrm{C}$ results in rapid regression of transient elastography and fibrosis markers fibrosis-4 score and aspartate aminotransferase-platelet ratio index. Liver Int 2017;37:36976.

119. Vilar-Gomez E, Martinez-Perez Y, Calzadilla-Bertot L, TorresGonzalez A, Gra-Oramas B, Gonzalez-Fabian L, Friedman SL, Diago M, Romero-Gomez M. Weight loss through lifestyle modification significantly reduces features of nonalcoholic steatohepatitis. Gastroenterology 2015;149:367-78.e5; quiz e14-5.

120. Wong VW, Chan RS, Wong GL, Cheung BH, Chu WC, Yeung DK, Chim AM, Lai JW, Li LS, Sea MM, Chan FK, Sung JJ, Woo J, Chan HL. Community-based lifestyle modification programme for nonalcoholic fatty liver disease: a randomized controlled trial. $J$ Hepatol 2013;59:536-42.

121. Boettcher E, Csako G, Pucino F, Wesley R, Loomba R. Meta-analysis: pioglitazone improves liver histology and fibrosis in patients with non-alcoholic steatohepatitis. Aliment Pharmacol Ther 2012;35:6675.

122. Mahady SE, Webster AC, Walker S, Sanyal A, George J. The role of thiazolidinediones in non-alcoholic steatohepatitis - a systematic review and meta analysis. J Hepatol 2011;55:1383-90.

123. Singh S, Khera R, Allen AM, Murad MH, Loomba R. Comparative effectiveness of pharmacological interventions for nonalcoholic steatohepatitis: a systematic review and network meta-analysis. Hepatology 2015;62:1417-32.

124. Neuschwander-Tetri BA, Loomba R, Sanyal AJ, Lavine JE, Van Natta ML, Abdelmalek MF, Chalasani N, Dasarathy S, Diehl AM, Hameed B, Kowdley KV, McCullough A, Terrault N, Clark JM, Tonascia J, Brunt EM, Kleiner DE, Doo E, Network NCR. Farnesoid $\mathrm{X}$ nuclear receptor ligand obeticholic acid for non-cirrhotic, nonalcoholic steatohepatitis (FLINT): a multicentre, randomised, placebo-controlled trial. Lancet 2015;385:956-65.

125. Kleiner DE, Brunt EM, Van Natta M, Behling C, Contos MJ, Cummings OW, Ferrell LD, Liu YC, Torbenson MS, Unalp-Arida A, Yeh M, McCullough AJ, Sanyal AJ, Nonalcoholic Steatohepatitis Clinical Research N. Design and validation of a histological scoring system for nonalcoholic fatty liver disease. Hepatology 2005;41:131321.

126. Moon HJ, Finney J, Ronnebaum T, Mure M. Human lysyl oxidaselike 2. Bioorg Chem 2014;57:231-41.

127. Wong VW, Chitturi S, Wong GL, Yu J, Chan HL, Farrell GC. Pathogenesis and novel treatment options for non-alcoholic steatohepatitis. Lancet Gastroenterol Hepatol 2016;1:56-67.

128. Gilead Terminates Phase 2 Study of Simtuzumab in Patients With Idiopathic Pulmonary Fibrosis. Available from: http://www.gilead. com/news/press-releases/2016/1/gilead-terminates-phase-2-studyof-simtuzumab-in-patients-with-idiopathic-pulmonary-fibrosis. [Last accessed on 26 July 2017].

129. Loomba R, Lawitz E, Mantry PS, Jayakumar S, Caldwel SHea. GS4997, an inhibitor of apoptosis signal-regulating kinase (ASK1), alone or in combination with simtuzumab for the treatment of non-alcoholic 
steatohepatitis (NASH): a randomized, phase 2 trial. Hepatology 2015;63:1254A.

130. Berres ML, Koenen RR, Rueland A, Zaldivar MM, Heinrichs D, Sahin H, Schmitz P, Streetz KL, Berg T, Gassler N, Weiskirchen R, Proudfoot A, Weber C, Trautwein C, Wasmuth HE. Antagonism of the chemokine $\mathrm{Ccl} 5$ ameliorates experimental liver fibrosis in mice. $J$ Clin Invest 2010;120:4129-40.

131. Mitchell C, Couton D, Couty JP, Anson M, Crain AM, Bizet V, Renia L, Pol S, Mallet V, Gilgenkrantz H. Dual role of CCR2 in the constitution and the resolution of liver fibrosis in mice. Am J Pathol 2009;174:1766-75.

132. Sanyal A, Ratziu V, Harrison S, Abdelmalek MF, Aithal GP, Caballeria Jea. Cenicriviroc placebo for the treatment of nonalcoholic steatohepatitis with liver fibrosis: Results from the Year 1 primary analysis of the Phase $2 \mathrm{~b}$ CENTAUR study. Hepatology 2016;64:1118A.

133. Traber PG, Chou H, Zomer E, Hong F, Klyosov A, Fiel MI, Friedman SL. Regression of fibrosis and reversal of cirrhosis in rats by galectin inhibitors in thioacetamide-induced liver disease. PLoS One 2013;8:e75361.

134. Galectin Therapeutics Announces Achievement of Key Milestones Related to NASH-CX Clinical Trial. Available from: http://investor. galectintherapeutics.com/releasedetail.cfm?releaseid=1009928. [Last accessed on 30 June 2017].

135. Stenner J, Jazrawi R, Verma A, Ahmed H, Northfield T. Effect of UDCA on fibrosis markers in alcoholic liver disease. Clin Sci 2000;98:17p.

136. Kim MY, Cho MY, Baik SK, Jeong PH, Suk KT, Jang YO, Yea CJ, Kim JW, Kim HS, Kwon SO, Yoo BS, Kim JY, Eom MS, Cha SH, Chang SJ. Beneficial effects of candesartan, an angiotensin-blocking agent, on compensated alcoholic liver fibrosis - a randomized openlabel controlled study. Liver Int 2012;32:977-87.

137. Mudaliar S, Henry RR, Sanyal AJ, Morrow L, Marschall HU, Kipnes M, Adorini L, Sciacca CI, Clopton P, Castelloe E, Dillon P, Pruzanski M, Shapiro D. Efficacy and safety of the farnesoid X receptor agonist obeticholic acid in patients with type 2 diabetes and nonalcoholic fatty liver disease. Gastroenterology 2013;145:574-82 e1.

138. Nevens F, Andreone P, Mazzella G, Strasser SI, Bowlus C, Invernizzi P, Drenth JP, Pockros PJ, Regula J, Beuers U, Trauner M, Jones DE, Floreani A, Hohenester S, Luketic V, Shiffman M, van Erpecum KJ, Vargas V, Vincent C, Hirschfield GM, Shah H, Hansen B, Lindor KD, Marschall HU, Kowdley KV, Hooshmand-Rad R, Marmon T, Sheeron S, Pencek R, MacConell L, Pruzanski M, Shapiro D, Group PS. A placebo-controlled trial of obeticholic acid in primary biliary cholangitis. N Engl J Med 2016;375:631-43.

139. Zois CD, Baltayiannis GH, Karayiannis P, Tsianos EV. Systematic review: hepatic fibrosis - regression with therapy. Aliment Pharmacol Ther 2008;28:1175-87.

140. Huang Y, Deng X, Liang J. Modulation of hepatic stellate cells and reversibility of hepatic fibrosis. Exp Cell Res 2017;352:420-6.

141. Wu JR, Hu CT, You RI, Pan SM, Cheng CC, Lee MC, Wu CC, Chang
YJ, Lin SC, Chen CS, Lin TY, Wu WS. Hydrogen peroxide inducible clone-5 mediates reactive oxygen species signaling for hepatocellular carcinoma progression. Oncotarget 2015;6:32526-44.

142. Lei XF, Fu W, Kim-Kaneyama JR, Omoto T, Miyazaki T, Li B, Miyazaki A. Hic-5 deficiency attenuates the activation of hepatic stellate cells and liver fibrosis through upregulation of $\operatorname{Smad} 7$ in mice. J Hepatol 2016;64:110-7.

143. Schon HT, Bartneck M, Borkham-Kamphorst E, Nattermann J, Lammers T, Tacke F, Weiskirchen R. Pharmacological intervention in hepatic stellate cell activation and hepatic fibrosis. Front Pharmacol 2016;7:33

144. Tacke F, Trautwein C. Mechanisms of liver fibrosis resolution. $J$ Hepatol 2015;63:1038-9.

145. Puche JE, Saiman Y, Friedman SL. Hepatic stellate cells and liver fibrosis. Compr Physiol 2013;3:1473-92.

146. Pines M, Spector I. Halofuginone -- the multifaceted molecule. Molecules 2015;20:573-94.

147. Bruck R, Genina O, Aeed H, Alexiev R, Nagler A, Avni Y, Pines M. Halofuginone to prevent and treat thioacetamide-induced liver fibrosis in rats. Hepatology 2001;33:379-86.

148. Spira G, Mawasi N, Paizi M, Anbinder N, Genina O, Alexiev R, Pines M. Halofuginone, a collagen type I inhibitor improves liver regeneration in cirrhotic rats. J Hepatol 2002;37:331-9.

149. Breitkopf K, Haas S, Wiercinska E, Singer MV, Dooley S. Anti-TGFbeta strategies for the treatment of chronic liver disease. Alcohol Clin Exp Res 2005;29:S121-31.

150. Qi Z, Atsuchi N, Ooshima A, Takeshita A, Ueno H. Blockade of type beta transforming growth factor signaling prevents liver fibrosis and dysfunction in the rat. Proc Natl Acad Sci U S A 1999;96:2345-9.

151. Hayashi H, Sakai T. Biological significance of local tgf-beta activation in liver diseases. Front Physiol 2012;3:12.

152. Ribeiro SM, Poczatek M, Schultz-Cherry S, Villain M, MurphyUllrich JE. The activation sequence of thrombospondin-1 interacts with the latency-associated peptide to regulate activation of latent transforming growth factor-beta. J Biol Chem 1999;274:13586-93.

153. Kondou H, Mushiake S, Etani Y, Miyoshi Y, Michigami T, Ozono K A blocking peptide for transforming growth factor-betal activation prevents hepatic fibrosis in vivo. $J$ Hepatol 2003;39:742-8.

154. Kim SJ, Ise H, Kim E, Goto M, Akaike T, Chung BH. Imaging and therapy of liver fibrosis using bioreducible polyethylenimine/siRNA complexes conjugated with N-acetylglucosamine as a targeting moiety. Biomaterials 2013;34:6504-14.

155. Chatterjee A, Villarreal G, Jr., Rhee DJ. Matricellular proteins in the trabecular meshwork: review and update. J Ocul Pharmacol Ther 2014;30:447-63.

156. Gressner OA, Gressner AM. Connective tissue growth factor: a fibrogenic master switch in fibrotic liver diseases. Liver Int 2008;28:1065-79.

157. A Study of FG-3019 in Subjects With Liver Fibrosis Due to Chronic Hepatitis B Infection. Available from: https://clinicaltrials.gov/ct2/ show/NCT01217632. [Last accessed on 30 June 2017]. 